\title{
SCHENGEN HATÁRAI BIZTONSÁGPOLITIKAI - KIEMELTEN MIGRÁCIÓS - SZEMPONTBÓL NÉZVE
}

\section{(The Borders of Schengen from the Point of View of a Security and Migration Policy)}

\section{KOBOLKA ISTVÁN}

Magyarország a NATO-hoz való csatlakozásával, illetve az Európai Unióhoz (EU) való csatlakozási törekvésével ,peremállam” szerepre vállalkozott a keletközép-európai régióban. Ebböl adódóan jelenlegi helyzete bonyolultabbá vált Szomszédaihoz való viszonyát tekintve. Azok a körülmények, amelyek a NATO kibővítését megváltoztatták, és az a tény, hogy az EU-hoz való csatlakozásunk jóval hosszabb idöt vesz igénybe a tervezettnél, kettós hatást gyakorol Magyarországra a szomszédaihoz való viszonyát illetően. Egyrészt Magyarország közvetítô szerepet tölthet be a balkáni és kelet-európai államok integrációs törekvéseiben, másrészt egyes országok „kimaradása” a csatlakozásból illetve ennek érzete hazánk irányába negatív hatást vált ki, elsösorban az ott élö magyarsággal kapcsolatos kérdéseket illetően. A határőrizet és ellenőrzés tekintetében Magyarország hasonló helyzetbe került, mint korábban Ausztria.

A fenti helyzetet bonyolítja, hogy a bövítés előtt a NATO és EU tagországoknak új kihívásokkal kell szembenézniük, mint pl. az európai határok alakulása, a belső határok megszủnésének várható következményei.

Hazánk teljes jogú tagságra törekszik az EU-ban, de nemzeti érdekeit szem elött tartja. Természetesen az euro-atlanti stratégiához tartozik az is, hogy a NyugatEurópai Unióval (WEU) is együttmüködik. A WEU tagállamok 1987. évi hágai nyilatkozatukban rögzítették, hogy az európai integráció csak akkor lehet teljes, ha tartalmazza a biztonságot és a védelmet is.

Az 1992. évi Maastrichti szerzödés a WEU kettős szerepét fogalmazta meg, mely szerint egyfelől a WEU és az EU tagállamai közös védelempolitikájának tényezője, másfelöl a NATO ,európai pillére”, annak erősítő eszköze. Ennek megfelelően a tagállamok közös védelempolitikát alakítanak ki (Kis 1998). 1992. február 07-én a tizenkét tagállam által megkötött Maastrichti szerzödés alapján megszületett az EU, amely célul tüzte ki:

- a kiegyensúlyozott és fenntartható gazdasági és társadalmi fejlődés elömozdítását, különösen egy belső határok nélküli térség létrehozásával, gazdasági és pénzủgyi unió létrehozása által, amely egyetlen közös pénz kialakításával jár;

- az önazonosság megerősítését a nemzetközi színtéren, különösen a közös külés biztonságpolitika megvalósításával, közös védelem kialakításával;

- uniós állampolgárság létrehozását;

- szoros kapcsolat kialakítását az igazságszolgáltatás és a belügyek tekintetében;

- a közösségi mechanizmusok, intézmények továbbfejlesztését. 
Kobolka István : Schengen határai biztonságpolitikai - kiemelten migrációs - szempontból nézve.

Tér és Társadalom 14. évf. 2000/2-3. 265-273. p.

TÉT XIV. évf. 2000 2-3

Az elözőeket 1997-ben az Amszterdami Egyezménnyel egészítették ki, amely tartalmazza: a szabadságjogokat, a biztonság- és igazságügyet; az Unió és az állampolgár viszonyát; a hatékony külpolitikát; az Unió intézményeit; a szorosabb együttmüködést; a szerződések egyszerüsítését; és a gazdaságpolitikát is.

A Maastrichti Szerzödés három fö pilléren nyugszik:

- 1. pillér: a korábbi alapszerződések alapján került továbbfejlesztésre. Alapvetỏen az. Unió állampolgárságával; a Közösség politikájával (az áruk, személyek, szolgáltatások és a tőke szabad mozgása, gazdaságpolitika, kultúra, környezetvédelem stb.); a tengeren túli országokkal való társulással, illetve a Közösség szerveivel foglalkozik.

- 2. pillér: a közös kül- és belpolitika kérdéseit tartalmazza, amelynek lényege a tagállamok biztonságának erösítése; az Unió függetlenségének védelme; az emberi jogok és az alapvető szabadságjogok tiszteletben tartása, figyelemmel az ENSZ dokumentumaira.

- 3. pillér: a bel- és igazságügyi együttmüködést foglalja magában. Kiemelten figyel a menekültügyi politikára; a bevándorlási politikára; a tagállamok külső határainak ellenőrzésére, különös tekintettel a kábítószer és szervezett bủnözés elleni harc feladataira.

Az elözőekben felsoroltak közül az Unió állampolgárait a legközvetlenebbül a személyek szabad mozgása érinti. Felméréseket végeztek, melyekböl kitủnt, hogy a lakosság nagy része tart a migráció okozta „,negatív" hatásoktól (tartanak a szervezett bünözés növekedésétöl illetve a munkalehetöségek csökkenésétől).

Öt állam (NSZK, Franciaország, Belgium, Hollandia, Luxemburg) már 1985-ben szerzödést kötött a luxemburgi Schengenben a közös határokon történő ellenörzés fokozatos megszüntetéséröl. Ugyanakkor a mai napig nem egységes az értelmezés a tekintetben, hogy az egyezmény harmadik ország állampolgáraira is vonatkozik-e vagy sem. Az egységes értelmezés hiánya jelentkezett öt évvel később (1990), amikor az alapítók megkötötték a Schengeni Végrehajtási Megállapodást (Schengeni II. Egyezmény), amely azonban a ratifikációs eljárások miatt csak 1993. szeptember 1-jén lépett életbe, és valójában csak 1995-ben emelkedett jogeröre.

Az EU egyik legjelentősebb problémája a migráció kérdése, melynek megoldására folyamatos törekvés tapasztalható. Ennek sorába tartozik az Amszterdami Szerződés végrehajtására született, a „Szabadság, Biztonság és Igazságosság Térségének" megvalósításáról szóló ún. Bécsi Akció Terv, amely a prioritások között jelöli meg többek között az illegális migráció elleni fellépést illetve annak megfelelö kezelését, messzemenỏen figyelembe véve a humanitárius szempontokat valamint az idegengyülöletre okot adó intézkedések kiküszöbölését is. Az Aszterdami Szerzödés és a Bécsi Akció Terv szellemében 1999 őszén megtartott tamperei találkozón az Unió a migrációs nyomás megfelelö kezelése érdekében az alábbiakat jelölte meg kiemelkedỏ fontosságú területként:

a) a kibocsátó és tranzit országokkal együttmüködve információs kampányok fejlesztése a legális bevándorlás lehetóségeiröl, valamint az emberkereskedelem megelőzésére; 
Kobolka István : Schengen határai biztonságpolitikai - kiemelten migrációs - szempontból nézve.

Tér és Társadalom 14. évf. 2000/2-3. 265-273. p.

Schengen határai...

267

b) a közös politika továbbfejlesztése a vízumokkal és hamis okmányokkal kapcsolatban, beleértve a harmadik ország területén müködő konzulátusok közötti együttmüködést;

c) hatékony fellépés az embercsempészés illetve valamennyi, az illegális migránsok helyzetét kihasználó, kizsákmányoló tevékenység ellen, súlyos büntetések alkalmazása az elkövetőkkel, résztvevőkkel szemben (a Tanácsnak 2000 végére el kellene fogadnia az e területet szabályozó normákat); A tagállamoknak az Europollal együttmúködve meg kell kísérelniük a csempészhálózatok felszámolását;

d) szorosabb együttmüködés és technikai segítségnyújtás kialakítása a tagállamok határörizeti szervei között, amelybe sürgősen be kell vonni a csatlakozó államokat is;

e) a csatlakozó államoknak teljes egészében meg kell valósítaniuk a schengeni szabályokban foglalt elvárásokat, a leendö külső határokat ellenörzỏ államoknak hatékony határörizetet kell kialakítaniuk speciálisan kiképzett hivatásos állomány alkalmazásával;

f) a tagállamoknak hatékony segítséget kell nyújtaniuk a kibocsátó és a tranzit országok számára az önkéntes hazatérés elösegitésére és az embercsempészés elleni megfelelő fellépés érdekében;

g) visszafogadási egyezményeket kell létrehozni az Európai Közösség és a harmadik országok között, megfontolandó továbbá az ún. belső (a Közösségen belüli) visszafogadási szabályok bevezetése (Az illegális migráció... 1999; Vass 1999).

Az EU tagállamai felismerték azt a tényt, hogy az illegális migráció egy olyan összetett jelenség, amelyet kizárólag szankciókkal megszuintetni nem lehet, ellene csak úgy tudnak fellépni hathatósan, ha a kibocsátó és befogadó országokat is bevonják, illetve szükség szerint segítséget nyưjtanak számukra.

Közismert tény, hogy az EU határellenörzési rendszere az ellenörzés módszereit tekintve ún. külső és belső határellenőrzési rendszerre tagozódik. (Belsö határok: a tagállamok közös szárazföldi határai, repülőterei - amelyek belső forgalmat bonyolítanak le -, illetve a tengeri kikötők - azok, amelyek anélkül bonyolítanak le forgalmat, hogy a felek területén kívül érintenének más kikötöt. Külsô határok: mindazok, az elöbbiek értelmében, amelyek nem belső határok).

Csatlakozásunk során belső határrá válhat (attól függően, hogy a szomszédos országok közül melyek válnak EU taggá az első körben):

a) az osztrák-szlovén $(458 \mathrm{~km})$;

b) az szlovák-osztrák-szlovén (1139 km) határszakasz.

Magyarország külső határainak hossza ennek értelmében 1784 km vagy 1103 km lesz.

Természetesen egy harmadik ország állampolgárainak ellenörzésére már a schengeni területeken kívül is van lehetőség. A vízumkötelezett országok polgárainak szürése már a külképviseleteken is megvalósulhat. 
Kobolka István : Schengen határai biztonságpolitikai - kiemelten migrációs - szempontból nézve.

Tér és Társadalom 14. évf. 2000/2-3. 265-273. p.

A migráció tekintetében a biztonsági rendszer legfontosabb eleme az országhatár. Meg kell jegyezni azt a tényt, hogy a közrend vagy nemzetbiztonsági érdekből a tagállamok ideiglenes jelleggel belső határaikon visszaállithatják a hagyományos hatảrellenőrzést. Tehát az, hogy semmilyen útiokmányt nem kell felmutatni a belsỏ határon, nem jelenti azt, hogy az illetönek nem kell érvényes útiokmánnyal rendelkeznie. A szigorú külső határellenőrzés szerepe éppen az, hogy a tagállamok területére csak olyan személyek lépjenek, akik megfelelnek a belépés feltételeinek, és nem veszélyeztetik a közbiztonságot.

Magyarország csatlakozási idöpontjának megállapításánál figyelembe kell venni azt a tényt, hogy valamennyi újonnan csatlakozó államnak az egyezmény aláirását követỏen azt ratifikálnia kell. Ezek után szigorú követelményeknek kell megfelelni, amelyet a tagállamok szakértőbizottságai ellenőriznek. Megítélésünk szerint, amennyiben Magyarország 2005-ben EU tagállam lesz, legalább 2 év ratifikáció + 1 év szakértői ellenőrzés után 2008-tól lehet a schengeni rendszert teljes joggal alkalmazni.

Természetesen a tagállamok területén a saját rendészeti szervek ellenőrzései tovább élnek. Pl. Ausztria, Németország a határtól $20-30 \mathrm{~km}$ mélységben is ellenőriz, amelyet ugyan másképpen neveznek, de valójában belső határellenőrzést hajtanak végre.

Az alábbiakban a külföldiek számarányát szeretnénk illusztrálni. A Magyar Köztársaság területére 1999-ben 32054051 külföldi állampolgár lépett be, akik közül:

$\begin{array}{lc}\text { osztrák } & 5724787 \text { fó } \\ \text { szlovák } & 4668778 \text { fó } \\ \text { román } & 4447382 \text { fö } \\ \text { horvát } & 3612476 \text { fó } \\ \text { német } & 3404454 \text { fó } \\ \text { jugoszláv } & 3085880 \text { fó } \\ \text { ukrán } & 1165422 \text { fó } \\ \text { szlovén } & 916523 \text { fö }\end{array}$

Forrás: Belügyminisztérium.

A bevándorlási engedéllyel rendelkező hazánkban élö külföldiek száma 1999-ben 71705 fö volt (ebböl román 30443 fó).

A számadatok is bizonyítják, hogy migrációs stratégiánkat az Európai Bizottság meghatározásai alapján - a nemzeti jelleget maximálisan figyelembe véve - kell megvalósítanunk, az alábbi szempontok szerint:

- intézkedések meghozatala a migrációs nyomás ellensúlyozására (gazdasági, adminisztratív stb.);

- hatékony ellenőrzés kialakítása feltételeinek megteremtése a bevándorlás kezelése érdekében (pl.: a munkáltatók és a munkavállalók ellenörzése) ( 1 . ábra);

- a törvényes bevándorlók helyzetének megerősítése (menedékjog reformja, reintegrációs programok stb.). 
Kobolka István : Schengen határai biztonságpolitikai - kiemelten migrációs - szempontból nézve.

Tér és Társadalom 14. évf. 2000/2-3. 265-273. p.

TÉT XIV. évf. 2000 -2-3

Schengen határai...

269

\section{1. ÁBRA}

A külföldiek foglalkoztatása feketemunkásként Magyarországon

(Illegal Employment of Foreigners in Hungary)

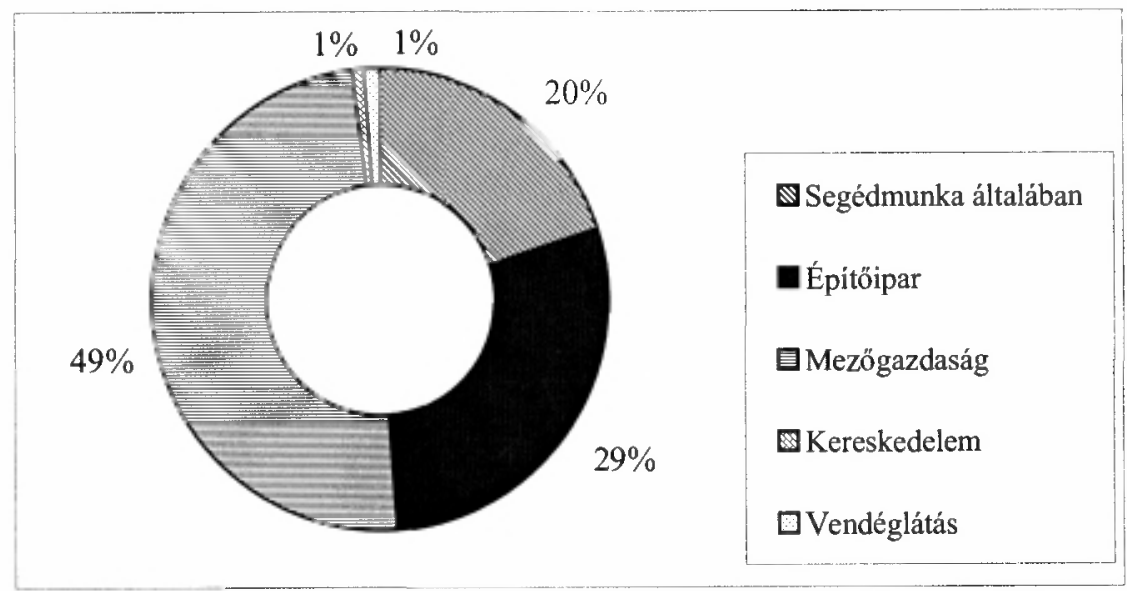

Forrás: BM, ORFK, ERÜBS.

Néhány terület azonnali fellépést és intézkedések meghozatalát igényli. Magyarországon 1999-ben az elkövetett büncselekmények miatti büntetöeljárás alá vont külföldiek száma 6332 fő volt (ebből román 2248 fö, jugoszláv 1202 fö).

A szervezett bủnözés nem egyszerü haszonszerzésre, hanem gazdasági jelentőségü profit megszerzésére törekszik. Ez a tevékenység 1990 óta ugrásszerủen megnött a határok megnyitásával. Megjelentek a külföldi szervezett búnözỏi körök, és a magyar bünözök külföldi kapcsolatokra tettek szert (föleg ukrán, orosz és kínai viszonylatban). A büncselekmények zöme Pest megyéhez (Budapest), illetve a nagyvárosokhoz kötődik. A Magyarországon elkövetett büncselekmények döntö többségét természetesen nem külföldiek követik el, mégis figyelmet érdemel a jelenség (2. ábra).

A külföldiek bünözése eltér az általános szerkezettöl. Társadalmi veszélyük nem létszámukból adódik, hanem a magas fokú bünözői aktivitásukból, és a mi kultúránkban idegen, kegyetlen bünözői szokásokból ered. (Az elkövetök többsége román, délszláv és ukrán.) Zömük tevékenysége mögött bünszövetkezeti tevékenység húzódik. Növekvő tendencia észlelhető az emberölés, embercsempészet, fegyverés lőszerkereskedelem, zsarolás, közokirat-hamisítás terén. Egyes külföldi bünözői csoportok megkezdték a harcot különböző területek és érdekeltségek létrehozásáért (Kunos 2000). A szervezett bünözés elleni tevékenységet nemzetközi szerzödések sora is segíti (pl. Romániával a szervezett bünözés, a terrorizmus és a kábítószer tiltott forgalma elleni harcban történő együttmüködésrơll szóló egyezményt kötött a Magyar Köztársaság 1997. február 19-én). 
Kobolka István : Schengen határai biztonságpolitikai - kiemelten migrációs - szempontból nézve.

Tér és Társadalom 14. évf. 2000/2-3. 265-273. p.

\section{2. ÁBRA}

A bünelkövetök számának alakulása és a külföldi elkövetōk részesedése Magyarországon 1989-1994

(The Development of the Number of Perpetrators and the Share of Foreign Perpetrators in Hungary between 1989 and 1994)

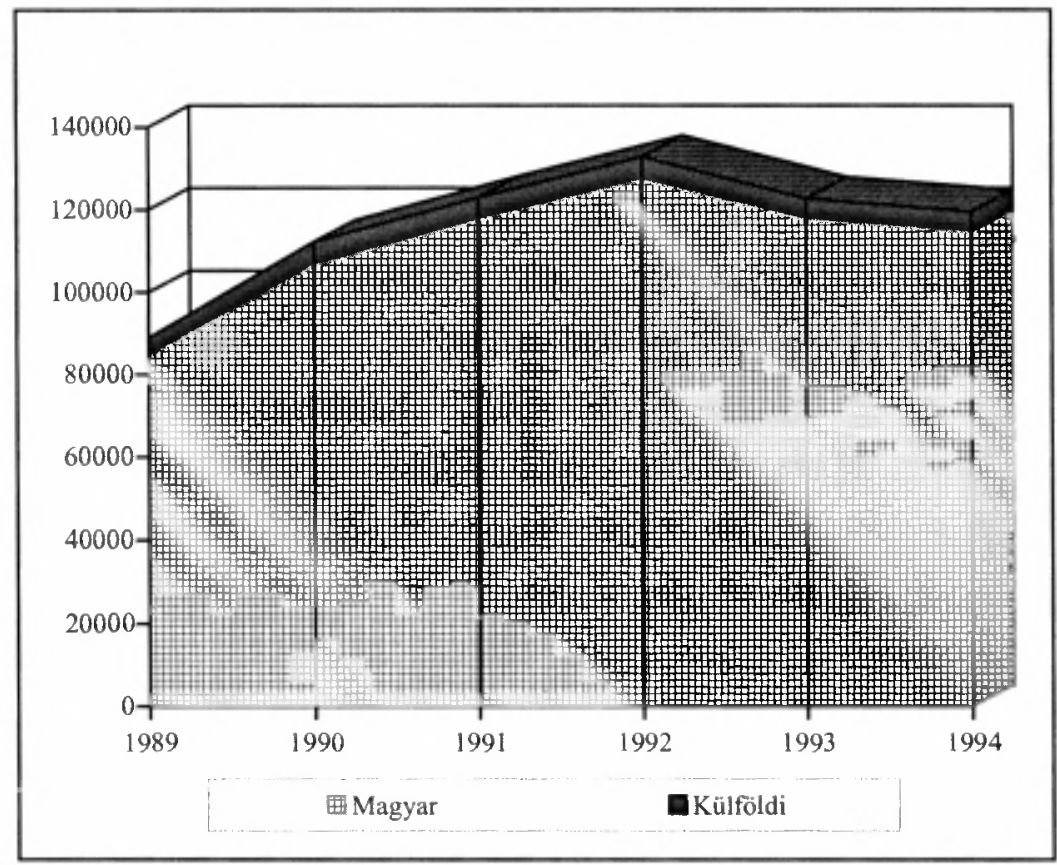

Forrás: BM, ORFK, ERÜBS.

Ami a migrációt illeti, jelenleg legalább 4-5 évre van szükség ahhoz, hogy az illegális migrációt megfékezzék. A jól felépített menekültügyi politika és a bevándorlási kérelmek gyors feldolgozása elősegítheti ezt a tevékenységet. 1998. március 1-jén hatályba lépett a menedékjogról szóló tỏrvény. Ezzel párhuzamosan feloldották a földrajzi korlátozást is, így a világ bármely országából kérhetnek nálunk menedéket. Hatálybaléptetés előtt, 1997-ben 177-en kértek menekültstátuszt, 1998-ban 7118 fö, míg 1999-ben 10 hónap alatt 10137 före emelkedett a kérelmezök száma.

A leggyakoribb eset az, hogy a migránsok legálisan utaznak be az ország területére, de illegálisan akarnak kiutazni nyugat felé. Mikor elfogják öket, idegenrendészeti eljárás indul ellenük, és kötelező tartózkodási helyet (közösségi szálás) jelölnek ki számukra. A leggyakrabban kiutasítják ezeket az embereket az országból, s ekkor meneküitstátuszt kérnek. (1999-ben 73 országból érkeztek illegálisan külföldiek.) A menekültstátusz határozatlan idöre, a „befogadott” elismerés egy évre szól (átmenetileg nem küldhetö vissza). A kérelmek elbírálására három hónap áll rendelkezésre. Ez idő alatt az embercsempész hálózatok 5-8000 DM vagy 2000 USD ellenében megszervezik a menekülők továbbszállitását. A szervezett bünözés elleni 
Kobolka István : Schengen határai biztonságpolitikai - kiemelten migrációs - szempontból nézve.

Tér és Társadalom 14. évf. 2000/2-3. 265-273. p.

TÉT XIV. évf. 2000 -2-3

Schengen határai...

271

törvény elfogadásával jelentős szigorítások következtek be, amelyek lassan éreztetni fogják hatásukat.

Magyarország célkitüzése, hogy az EU-hoz csatlakozik. A végső dátumon még lehet vitatkozni, de az egyértelmű, hogy nagyon hosszú előkészitő szakaszon kell végigmenni. Idáig azt mondták ránk, hogy a „legnyugatibb keleti ország” vagyunk. Most pedig a „legkeletibb nyugati országgá" válhatunk.

„Elmondhatjuk hogy a határon túli magyarság nem csupán Európa legnagyobb, hanem egyben legbékésebb nemzeti kisebbsége is, hiszen a század elsỏ negyedében bekövetkezett kisebbségi sorba kerülése óta mindenkor kizárólag békés eszközökkel próbálja a jogait érvényesíteni, miközben Európában számos olyan kisebbség él, amely a maga érdekének érvényesítésére alkotmányon kívüli eszközöket, akár erőszakot is alkalmaz. Sikerült bebizonyítani hogy a közép-európai magyar közösségek az adott országokban a demokratizálódás, a modernizáció, a piacgazdaságra való áttérés és az euro-atlanti integrálódás élenjárói. Ezt igazolta az RMDSZ kormányzati tevékenysége is."(Nagy 1998)

A határon túli magyarság új arculatához tartozik, hogy a magyarországi társadalom elött nemcsak a gondokat és a problémákat mutatja be, hanem mindazokat a kezdeményezéseket is, amelyeket a határon túli magyarság gyakran önerőből, illetve a magyar kormány támogatásával megvalósított a helyi modernizációban, az egyházak közösségépítésében és egyéb területeken. A magyar kormány törekvései között szerepelt a határokon átnyúló regionális kezdeményezések támogatása. A Kárpátok Eurorégió, a Duna-Körös-Maros-Tisza Regionális Együttmúködés, a Nyugat-Pannónia Eurégió, a Duna-Dráva-Száva Euroregionális Együttmüködés a jószomszédi kapcsolatok megteremtése mellett az évszázadok során kialakult gazdasági és kulturális kapcsolatok helyreállításának támogatására jött létre.

Magyarország csatlakozása a NATO-hoz és csatlakozási szándéka az EU-hoz kedvezö a magyarság számára. Magyarország nemzetközi tekintélyének növelésével, a befolyásolási lehetőség biztosításával, egyben a határon túli magyarok ügyének előmozdítását is segíti. A NATO és az EU bővítésének első köréből kimaradnak (kimaradtak) azok az államok, amelyekben jelentős lélekszámú magyar kisebbség él. Magyarország mint anyaország gazdasági fejlettsége és nemzetközi biztonsági pozíciójának erősödése új háttérként szolgálhat a határon túli magyarság számára az európai vérkeringésbe történő bekapcsolódáshoz. Ugyanakkor kulcsfontosságú, hogy az euro-atlanti integrálódás folyamatával párhuzamosan ne gyengüljön jelenlegi szomszédsági kapcsolatrendszerünk, és ne következzék be törés vagy zavar a kárpát-medencei magyar-magyar kapcsolatrendszerben.

Az integráció abból a szempontból is feltétlenül előnyt jelent számunkra, hogy a jelenleginél jobban tudunk hivatkozni az EU országaiban érvényesülö kisebbségpolitikai gyakorlatra. A magyar külpolitika eredményeként könyvelhetö el, hogy az EU tagországokkal sikerült elfogadtatni Magyarország határon túli magyarokkal kapcsolatos politikáját. Az EU külső határainak őrzése - mint azt korábban már ismertettük - ugyanakkor kötelező feladatokat szab a külső határokkal rendelkező tagállamok határrendészeti szerveire. A magyar diplomáciának fontos feladata, 
Kobolka István : Schengen határai biztonságpolitikai - kiemelten migrációs - szempontból nézve.

Tér és Társadalom 14. évf. 2000/2-3. 265-273. p.

hogy harmóniát keressen az integrálódás, a szomszédsági politika valamint Magyarország és a határon túli magyarság minél akadálymentesebb, zavartalanabb érintkezése követelményei között.

Támogatni kell a szomszéd országok integrálódási törekvéseit, mivel ellenkező esetben a határon túli magyarság nemcsak az európai folyamatokból rekesztődne ki, de veszélybe kerülne nemzetünk civilizációs-kulturális egybetartozása is. Fontos a szomszédos országokkal való kapcsolatok fejlesztése. Ennek egyik eleme a nemzeti kisebbségek jogainak érvényesítése, ugyanakkor nem elfogadható a kétoldalú viszony kizárólag e kérdéskörre történő szúkítése.

\section{TÁBLÁZAT}

Külföldi állampolgárok számára kiadott, érvényben lévö munkavállalási engedélyek száma és aránya Magyarországon, 1998. június 30-án

(The Number and Share of Valid Working Papers for Foreign Subjects in Hungary in 30 June 1998)

\begin{tabular}{lcc}
\hline \multirow{2}{*}{ Állampolgárság } & \multicolumn{2}{c}{ Érvényes munkavállalási engedélyek } \\
\cline { 2 - 3 } & száma (fö) & aránya (\%) \\
\hline román & 10137 & 47,4 \\
kínai & 850 & 4,0 \\
kis-jugoszláviai & 751 & 3,5 \\
brit & 628 & 2,9 \\
amerikai (USA) & 595 & 2,8 \\
horvát & 200 & 0,9 \\
.. & $\ldots \ldots$ & $\ldots$ \\
további 90 állambeli & 246 & 5,8 \\
mindösszesen & 21401 & 100,0 \\
\hline
\end{tabular}

Forrás: BM.

A közeljövőben napvilágra kerülö törvény alanyi jogon biztosit munkavállalási lehetőséget a határon túli magyaroknak. (A tervek szerint legfeljebb évi három hónap idötartamban, az anyaországi magyarokhoz hasonló feltételek szerint.) A szabályozó részeket a szomszédos országokkal kötött kétoldalú megállapodások fogják rögzíteni. Romániával évente 8000 munkavállalót és hétszáz gyakornokot fogadnak kölcsönösen.

Befejezésként idézzuik Sadako Ogata, az ENSZ menekültügyi föbiztosának szavait: „A 21. század elött az a kihivás áll, hogy biztonságot tud-e adni a népeknek. Addig azonban, amíg az emberek nem érzik biztonságban magukat saját otthonaikban, továbbra is veszély fenyegeti az államok biztonságát."

\section{Irodalom}

Az illegális migráció. (1999) EU lanulmány. Budapest, Belügyminisztérium.

Kis J.L. (1998) A közös kül-és biztonságpolitika. Európa ma és holnap. Budapest, Balassi Kiadó.

Kunos I. (2000) Bünözés a huszadik század végén. Budapest, ORFK.

Nagy G. (1998) Határon túli magyarság és a magyar kisebbségpolitika az integráció tükrében. Kézirat.

Vass G. (1999) A Schengeni rendszer és a biztonság. A közrend és a közbiztonság védelme egy bels” határok nélküli térségben. Budapest, TIT. HABE. Nyári Egyetem. 
Kobolka István : Schengen határai biztonságpolitikai - kiemelten migrációs - szempontból nézve.

Tér és Társadalom 14. évf. 2000/2-3. 265-273. p.

TÉT XIV. évf. 2000 - 2-3

Schengen határai...

273

\section{THE BORDERS OF SCHENGEN FROM THE POINT OF VIEW OF A SECURITY AND MIGRATION POLICY}

\section{ISTVÁN KOBOLKA}

Hungary took on the role of a border state in the Central and Eastern Europe when joining to the NATO and its endeavour in joining the European Union (EU). Therefore its present situation has become more complicated with regard to its relationships with the neighbour states.

The circumstances have changed the enlargement process of NATO and the fact that the EU accession is taking longer than planned has two different effects on Hungary in the point of view of its relationships with the neighbours. On the one hand it may play an intermediary role in the integration endeavours of countries in the Balkan and in the eastern part of Europe. On the other hand the integration process has some negative effects on Hungary, once case is the stricter border will possibly seperate Hungarian minorities living in neighboring countries.

As Austria was before, now Hungary is responsible for guarding and controlling the border. This study summarises the problems Hungary now has to face in connection with the crimes committed by refugees and foreigners. Finally, it forecasts the problems appearing with the EU accession and the Schengen Agreement. These problems have special importance because of the considerable Hungarian minority that lives in countries missing from EU enlargement. 